Journal of BANKING \&

FINANCE

ELSEVIER

Journal of Banking \& Finance 23 (1999) 1521-1533

www.elsevier.com/locate/econbase

\title{
Lessons from the Tequila Crisis
}

\author{
Frederic S. Mishkin ${ }^{\mathrm{a}, \mathrm{b}, *}$ \\ a Graduate School of Business, Columbia University, Uris Hall 619, New York, NY 10027, USA \\ ${ }^{\mathrm{b}}$ National Bureau of Economic Research, Cambridge, MA 02138, USA
}

\begin{abstract}
This paper draws several important lessons from the Tequila Crisis of 1994 and 1995. The overriding lesson is that the dynamics of financial crises in emerging market countries differ from those in industrialized countries because institutional features of their debt markets differ. Several policy lessons for emerging market countries also emerge from the analysis: (1) pegged exchange-rate regimes are extremely dangerous, (2) strong prudential supervision of the banking system is critical for prevention of financial crises, (3) financial liberalization must be managed extremely carefully and (4) different policies are needed to promote recovery in emerging market countries than those that are applicable to industrialized countries. (C) 1999 Elsevier Science B.V. All rights reserved.
\end{abstract}

JEL classification: F3; E5; G2

Keywords: Financial crisis; Mexico; Lender of last resort; Banking

The Tequila Crisis of 1994 and 1995 provides many important lessons for emerging market countries. Indeed, one of the most important overriding lessons is that in order to understand what happened during the Tequila Crisis, economists must take account of the key differences in the institutional framework of financial systems in emerging market countries from those in industrialized countries. An implication is that economists from industrialized

\footnotetext{
"Tel.: 1-212-854-3488; fax: 1-212-316-9219; e-mail: fsm3@columbia.edu 
countries must not be country-centric: they must recognize that policy approaches to prevent and cope with financial crises in industrialized countries may not be appropriate for emerging market countries because of particular features of their institutional structure.

\section{Lessons for financial crises}

There are two key differences from industrialized countries in the institutional structure in emerging market countries - Mexico is a clear cut example - that make a huge difference in the dynamics of banking and financial crises.

1. Private debt contracts have very short duration.

2. Many debt contracts are denominated in foreign currencies.

For example, in emerging market countries like Mexico, private debt contracts are repriced at least once a month, so that the durations of this debt are very short. In contrast, private debt contracts in industrialized countries such as the US are much longer, with durations commonly extending to many years. An important reason why this occurs is that emerging market countries have typically experienced very high and variable inflation rates, so that the inflation risk in long-duration debt contracts is extremely high relative to that found in industrialized countries. Short-duration debt contracts then dominate because they bear much less inflation risk.

High and variable inflation is also a driving force behind the second institutional feature of financial markets in emerging market countries. High and variable inflation leads to tremendous uncertainty about the future value of the domestic currency in emerging market countries. Thus, many nonfinancial firms, banks and governments in emerging market countries find it much easier to issue debt if it is denominated in foreign currencies. This was a prominent feature of the institutional structure in Chilean financial markets before the financial crisis in 1982 and in Mexico in 1994.

What are the implications of these two institutional features for the dynamics of financial crises in emerging market countries?

The first implication is that, in contrast to what happens in most industrialized countries, in emerging market countries a foreign exchange crisis is a major precipitating factor that leads to a financial crisis. To see this, we must understand what a financial crisis is all about. In recent years, a

\footnotetext{
${ }^{1}$ See Mishkin (1996) for a more detailed exposition of the dynamics of financial crises in emerging market countries.
} 
modern, asymmetric information, theory of financial crises has been developing. ${ }^{2}$ The basic idea of this theory is that a financial crisis is a situation in which information flows in financial markets get disrupted so that financial markets cannot do their job: i.e., financial markets are no longer able to efficiently channel funds to those who have the most productive investment opportunities. When this happens, the result is a sharp drop in investment, both business and household and a sharp contraction in economic activity.

So how does a foreign exchange crisis lead to a financial crisis? With debt contracts denominated in foreign currency, when there is a large unanticipated depreciation or devaluation of the domestic currency, the debt burden of domestic firms shoots up sharply. Since assets of these firms are typically denominated in domestic currency, there is no matching rise in the value of assets when the value of the liabilities rise, so there is a sharp deterioration of firms' balance sheets and a large decline in net worth. When firms have less net worth, asymmetric information problems in financial markets increase and can lead to a financial crisis and a sharp contraction in economic activity.

There are several reasons why the decline in net worth stemming from an exchange rate crisis can provoke a financial crisis and depression. First, net worth performs a role similar to that of collateral which helps reduce adverse selection problems in credit markets. If a firm has a decline in net worth, lenders have less to grab on to if the firm defaults on its debt and so will not want to lend it. In addition, with less net worth, a firm is more likely to default because it has a smaller cushion of assets that it can use to pay off its debt.

An even more important reason why firms will have less access to credit when their net worth deteriorates is that a decline in net worth increases the incentives for firms to engage in moral hazard. Less net worth means that firms now have less at stake and thus less to lose if they default on their loans. Therefore, the incentives for them to take on a lot of risk becomes very high. The most extreme case of this moral hazard occurs when net worth declines so much that a firm is insolvent. Then the firm has tremendous incentives to make huge bets in the hope of getting out of the hole. Thus lenders have an additional reason for shying away from lending to firms when their net worth declines. A deterioration in firms' balance sheets resulting from a collapse of the domestic currency thus increases adverse selection and moral hazard problems in financial markets which

\footnotetext{
${ }^{2}$ For example, see Bernanke (1983), Calomiris and Gorton (1991), and Mishkin (1991, 1994, 1996).
} 
cuts off lending, provokes a financial crisis and produces a severe decline in economic activity.

A foreign exchange crisis can also precipitate a banking crisis, with additional devastating effects on the economy. The fact that private debt is often denominated in foreign currencies in emerging market countries is a key to understanding how a foreign exchange crisis helps produce banking crises which are so harmful to these countries. Because of prudential regulations which force banks to match the value of assets and liabilities denominated in foreign currencies, it is not obvious that depreciation of the domestic currency should adversely affect bank balance sheets. ${ }^{3}$ However, this is not the case. Although the matching of foreign-denominated assets and liabilities makes it appear that banks have no market risk from exchange rate changes, in effect they do. When a devaluation occurs, although the value of foreign-denominated assets looks like it rises to match the increase in foreign-denominated liabilities, it does not. In emerging market countries such as Mexico, banks' foreign-denominated assets are typically dollar loans to domestic firms. As we have seen, when there is a devaluation, the firms with these dollar loans suffer a severe deterioration in their balance sheets because the value of their liabilities denominated in foreign currency shoots up, while the value of their assets denominated in domestic currency does not. The result is that these borrowers from banks are unable to pay back their loans and so banks find that as their dollar-denominated liabilities rise in value, their dollar-denominated loans, if anything, are likely to fall in value. Thus, the currency devaluation leads to a deterioration in banks' balance sheets because the foreign exchange risk for borrowers is converted to a credit risk for banks that have made the foreign currency denominated loans.

The deterioration in banks' balance sheet arising from the currency devaluation is harmful to the economy because banks play an extremely important role in the financial systems, especially in emerging market countries. Banks have particular advantages over other financial intermediaries in solving asymmetric information problems. For example, banks' advantages in information collection activities are enhanced by their ability to engage in long-term customer relationships and issue loans using lines of credit arrangements. Banks also have advantages in reducing moral hazard because, as demonstrated by Diamond (1984), they can engage in lower cost monitoring than individuals and because, as pointed out by Stiglitz and Weiss (1983), they have advantages in preventing risk taking by borrowers since they can use the threat

\footnotetext{
${ }^{3}$ As Garber and Lall (1996) document, banks in Mexico also exposed themselves directly to foreign-exchange risk and got around these prudential regulations by engaging in undisclosed offbalance sheet and offshore derivatives contracts. These activities were thus another reason why banks' balance sheets deteriorated as a result of the collapse of the domestic currency.
} 
of cutting off lending in the future to improve a borrower's behavior. Banks' natural advantages in collecting information and reducing moral hazard explain why banks have such an important role in financial markets throughout the world. Furthermore, the greater difficulty of acquiring information on private firms in emerging market countries makes banks even more important in the financial systems of these countries. ${ }^{4,5}$

When banks suffer a deterioration in their balance sheets as a result of a foreign exchange crises and so have a substantial contraction in their capital, they have two choices: either (1) they can cut back on their lending in order to shrink their asset base and thereby restore their capital ratios, or (2) they can try to raise new capital. However, when banks experience a deterioration in their balance sheets, it is very hard for them to raise new capital at a reasonable cost. Thus, the typical response of banks with weakened balance sheets is a contraction in their lending, which slows down the economic activity. If the deterioration in bank balance sheets is severe enough, however, it can have even more drastic effects on bank lending if it leads to bank panics, in which there are multiple, simultaneous failures of banking institutions. Because, as we have seen, banks have a special role in the economy, the resulting decline in bank lending after a collapse in the value of the domestic currency leads to a sharp contraction in economic activity.

The other institutional feature of financial systems in emerging market countries listed above - the fact that debt is of very short duration - suggests another reason why a foreign exchange crisis can have such devastating effects on these countries' economies. Because of their past history of high inflation, when there is a devaluation in emerging market countries, the nominal anchor of the pegged exchange rate has been shattered so that there is an immediate jump in expected inflation. The result is that nominal interest rates climb dramatically. The fact that debt is of very short duration means that the cash flow of both banks and firms deteriorate sharply; interest payments immediately shoot up and cash flow declines because the debt is repriced very quickly. The decline in cash flow and the resulting deterioration in firms' balance sheets means that lenders are less likely to lend to these firms because of increased adverse selection and moral hazard problems. As a result, the sharp increase in

\footnotetext{
${ }^{4}$ Rojas-Suarez and Weisbrod (1994) document that banks play a more important role in the financial systems in emerging market countries than they do in industrialized countries.

${ }^{5}$ As pointed out in Edwards and Mishkin (1995), the traditional financial intermediation role of banking has been in decline in both the United States and other industrialized countries because of improved information technology which makes it easier to issue securities. Although this suggests that the declining role of traditional banking which has been occurring in the industrialized countries may eventually occur in the developing countries as well, the barriers to information collection in developing countries are so great that the dominance of banks in these countries will continue for the foreseeable future.
} 
interest rates that occurs after a foreign exchange crisis helps provoke a financial crisis and a devastating contraction in economic activity.

The stories I have told here of how a foreign exchange crisis leads to banking and financial crises in emerging market countries is what we saw happen in Mexico. Indeed, this story has been very common in many other Latin American countries as well, Chile in the early 1980s being another example. Key elements in these stories are the two institutional features listed above that are specific to emerging market countries: that debt is often denominated in foreign currency and is of very short duration. In contrast, in most industrialized countries, little debt is denominated in foreign currency and is of much longer duration. As a result, foreign exchange crises do much less damage to the economy in industrialized countries. This explains why countries such as the UK were not hurt by the exchange rate crisis in September 1992. Indeed, the UK, seems to have benefitted from the depreciation of its currency after that crisis, in contrast to Mexico in 1994-1995 which was devastated by its foreign exchange crisis. An important lesson here from the Tequila Crisis is that different institutional structures can lead to very different outcomes when the value of the domestic currency changes.

\section{Policy lessons}

What are some of the policy lessons from the above analysis? Here we examine four basic lessons: (1) the dangers of pegged exchange-rate regimes, (2) the importance of strong prudential supervision of the banking system for prevention of financial crises, (3) the importance of managing financial liberalization and (4) the need for different policies to promote recovery in emerging market countries from those applicable to industrialized countries.

\subsection{The dangers of pegged exchange rate regimes}

One lesson from the Tequila Crisis is how dangerous a pegged exchange rate regime can be for emerging market countries. ${ }^{6}$ As we have seen in the above analysis of financial crises in emerging market countries, a speculative attack on the exchange rate that results in a devaluation can have devastating effects on the economy by interfering with information flows in financial markets. With a pegged exchange rate regime, depreciation of the domestic currency when it occurs is a highly nonlinear event because it involves a devaluation. The resulting dramatic increase in interest rates and rise in indebtedness which

\footnotetext{
${ }^{6}$ See Mishkin (1998) for a further discussion of the dangers of pegged exchange-rate regimes for emerging market countries.
} 
results in a sharp deterioration in firms' and banks' balance sheets then tips the developing country into a full scale financial crisis, with devastating effects on the economy. Thus, a pegged exchange rate regime with the institutional features outlined above is like putting the economy on a knife edge. One slip and the economy comes crashing down. The reason that some developing countries have chosen to peg their currency to a stable currency like the dollar is because they are seeking a nominal anchor that will promote price stability. However, if they have an institutional structure of a fragile banking system, short duration debt contracts and substantial debt denominated in foreign currencies, this is a very dangerous strategy indeed.

Another serious problem with a pegged or fixed exchange rate regime is that, if a floor is reached, there are no daily fluctuations in the exchange rate that can provide signals which help constrain policymakers to produce good monetary policy. Financial markets in many countries are now able to constrain politicians and policymakers to produce better monetary policy. In the US, the bond market fulfils this role. Indeed, one reason why politicians have been less likely to criticize Fed tightening to ward off future inflation in recent years is that they know that if they criticize Fed tightening, increased expectations of inflation will cause the bond market to tank. Avoiding a bond market collapse thus encourages better behavior in the political process.

Because emerging market countries rarely have developed bond markets, the foreign exchange market with flexible rates is needed to provide a similar role. When policies are undertaken that suggest that inflation is more likely to spin out of control, a flexible exchange rate will depreciate and become a signal to the central bank and to the public that the policy is too expansionary and needs to be revised. In addition, fears of a depreciating exchange rate may constrain politicians from criticizing central bank policies to keep inflation low and to preserve the value of the currency. Thus, the daily fluctuations in the exchange rate can provide an early warning signal that policies may have to be adjusted in order to limit the potential for a foreign exchange crisis, which in turn can lead to a financial crisis. A pegged or fixed exchange rate regime has the disadvantage that the foreign exchange market loses the ability to provide market signals that promote better policymaking. ${ }^{7}$

\subsection{Prudential supervision}

There is a second lesson that comes out of the experience with the Tequila Crisis. Strong prudential supervision of the banking system is crucial to the health of emerging market economies and the prevention of financial crises.

\footnotetext{
${ }^{7}$ Obstfeld and Rogoff (1995) and Stockman (1999), presented at this conference, provide additional arguments why pegged exchange rate regimes may be undesirable.
} 
Clearly good prudential supervision is important to industrialized countries. However, because the consequences of poor prudential supervision are so disastrous in emerging market countries, good prudential supervision is even more critical in these countries.

Why is prudential supervision especially important in emerging market countries? One reason is that the financial markets are not as well developed in emerging market countries - hence the name - with the result that banks play an even more important role in channelling funds to those with productive investment opportunities in these countries than in industrialized countries. ${ }^{8}$ Thus, poor prudential supervision which makes a banking crisis more likely has even greater ramifications because the collapse of the banking system does greater harm to the economy.

Another reason why prudential supervision is so important in emerging market countries is that a weak banking sector can help precipitate a foreign exchange crisis, which as we have seen, can precipitate a full-blown financial crisis. The importance of problems in the banking sector as a factor leading to foreign exchange crises has not received sufficient attention in the literature and in some papers in this conference. ${ }^{9}$

Weak prudential supervision which has helped lead to a deterioration in banks' asset quality can present a central bank with a difficult dilemma when a speculative attack on the currency occurs. In order to fight off a speculative attack, a central bank must be prepared to defend its currency by sharply raising interest rates. On the other hand, if interest rates are raised, this will cause a further deterioration in bank balance sheets. The negative effect on bank balance sheets occurs because banks typically have assets with longer durations than their liabilities, a consequence of their traditional financial intermediation activity of borrowing short and lending long. As a result, higher interest rates lead to a decline in the value of assets that is greater than the decline in the value of liabilities, leading to a deterioration in net worth. Furthermore, higher interest rates hurt bank borrowers, making it harder for them to pay back their loans, leading to increases in loan losses for banks, adding to the deterioration of bank balance sheets. Thus, when the central bank is confronted with a speculative attack, it is caught between the proverbial rock and a hard place, making the defense of the currency with increases in interest rates highly problematic. Once speculators understand that the central bank may therefore be more reluctant to defend the currency with interest rate increases, then a speculative attack is more likely to succeed, with the result that the speculative attack is more likely to occur.

\footnotetext{
${ }^{8}$ See Rojas-Suarez and Weisbrod (1994).

${ }^{9}$ Gavin and Hausman (1995) and Kaminsky and Reinhart (1996), which link banking crises to foreign exchange crises, are exceptions.
} 
The situation outlined here seems to be the one faced by the Bank of Mexico in 1994, and it is highly likely that the problems in Mexico's banking system in 1994 were an important factor leading to the foreign exchange crisis in December 1994. Poor prudential supervision can thus lead to the following vicious circle - banking crisis, which then promotes a foreign exchange crisis, which then promotes an even worse banking crisis. Strong prudential supervision can help break this vicious circle and is thus critical to the health of emerging market economies.

Encouraging a strong bank regulatory/supervisory system takes several forms. ${ }^{10}$ First, bank regulatory/supervisory agencies need to be provided with adequate resources to do their job effectively. Without these resources, the bank supervisory agency will not be able to monitor banks sufficiently in order to keep them from engaging in inappropriately risky activities, to have the appropriate management expertise and controls to manage risk, or to have sufficient capital so that moral hazard incentives to take on excessive risk are kept in check. Indeed, this inability to monitor banks sufficiently has occurred in both industrialized countries (e.g., the S\&L crisis in the US) and in many emerging market countries with Mexico being just one prominent example.

Second, accounting and disclosure requirements for financial institutions, which are often particularly lacking in emerging market countries but in a number of industrialized countries as well, need to be beefed up considerably. Without the appropriate information, both markets and bank supervisors will not be able to adequately monitor the banks to deter excessive risk-taking. Proper accounting standards and disclosure requirements are therefore crucial to a healthy banking system.

Third, prompt corrective action by bank supervisors will stop undesirable bank activities and even more importantly, not only close down institutions that do not have sufficient net worth, but also make sure that stockholders and managers of insolvent institutions are appropriately punished. Prompt corrective action is particularly important in part because it immediately prevents banks from "betting the bank" in order to restore the value of the institution and in part because it creates incentives for banks not to take on too much risk in the first place, knowing that if they do so, they are more likely to be punished.

Fourth, because prompt corrective action is so important, the bank regulatory/supervisory agency needs sufficient independence from the political process in order that it is not encouraged to sweep problems under the rug

\footnotetext{
${ }^{10}$ See Calomiris (1999), presented at this conference, for an additional discussion of measures that need to be taken to improve prudential supervision and reduce excessive risk-taking on the part of banks.
} 
and engage in regulatory forbearance. One way to ensure against regulatory forbearance is to give the bank supervisory role to a politically independent central bank. This has desirable elements as pointed out in Mishkin (1992), but some central banks might not want to have the supervisory task thrust upon them because they worry that it might increase the likelihood that the central bank would be politicized, thereby impinging on the independence of the central bank. Alternatively, bank supervisory activities could be housed in a bank regulatory authority that is independent of the government.

Fifth, it is important to make bank supervisors accountable if they engage in regulatory forbearance in order to improve incentives for them to do their job properly. For example, as pointed out in Mishkin (1997), an important but very often overlooked part of the 1991 FDICIA Act in the United States which has helped make this legislation effective is that there is a mandatory report that the supervisory agencies must produce if the bank failure imposes costs on the Federal Deposit Insurance Corporation (FDIC). The resulting report is made available to any member of Congress and to the general public upon request and the General Accounting Office must do an annual review of these reports. Opening up the actions of bank supervisors to public scrutiny makes regulatory forbearance less attractive to them, thereby reducing the principal agent problem. In addition, subjecting the actions of bank supervisors to public scrutiny reduces the incentives of politicians to lean on supervisors to relax their supervision of banks.

\subsection{Financial liberalization}

Deregulation and liberalization of the financial system have swept through almost all countries in the recent years. The importance of preventing banking crises in emerging market countries, however, suggests that financial liberalization may need to be phased gradually. If the proper bank supervisory structure is not in place when liberalization comes, the appropriate constraints on risk-taking behavior may be nonexistent, with the result that bank balance sheets are likely to suffer difficulties in the future. In addition, before liberalization occurs, banks may not have the expertise to make loans wisely and so opening them up to new lending opportunities too quickly may also lead to poor quality of the loan portfolio.

Indeed, financial deregulation and liberalization often lead to lending booms, both because of increased opportunities for bank lending and also because of financial deepening in which more funds flow into the banking system. Although liberalization and financial deepening are positive developments for the economy in the long run, in the short run, the lending boom may outstrip the available information resources in the financial system, helping to promote a financial collapse in the future. Lending booms have been a feature of financial liberalization in many countries and have often been followed by 
banking crises. ${ }^{11}$ Indeed, the deterioration in bank balance sheets in Mexico before the Tequila Crisis followed in the wake of a classic lending boom. ${ }^{12}$ One lesson from the Tequila Crisis is that policies to rein in lending booms may be needed to prevent banking and financial crises in emerging market countries.

The dangers in financial deregulation and liberalization do not mean that countries should not pursue a liberalization strategy. On the contrary, financial liberalization is critical to the efficient functioning of financial markets so that they can channel funds to those with the most productive investment opportunities. Getting funds to those with the most productive investment opportunities is especially critical to emerging market countries because these investments can have especially high returns, thereby stimulating rapid economic growth. Financial deregulation and liberalization thus need to be actively pursued, but have to be managed carefully. It is important that policymakers put in place the proper bank regulatory/supervisory institutional structure before liberalizing their financial systems. This means following the precepts outlined above: providing sufficient resources to bank supervisors, adopting adequate accounting and disclosure requirements, encouraging bank supervisors to take prompt corrective action, and insulating bank supervision from the political process. Furthermore, policymakers may need to pursue financial liberalization at a measured pace in order to keep a lending boom from getting out of hand which, in turn, stresses the capabilities of both bank management and bank supervisors.

\subsection{Policies to recover from financial crises}

The last lesson, I would like to draw is that traditional measures used in industrialized countries to extirpate themselves from financial crises may be counterproductive in emerging market countries. In industrialized countries, the standard prescription for emerging from a financial crisis is for the central bank to become a lender of last resort and to pursue expansionary monetary policy. Suppose that an expansionary monetary policy were followed in an emerging market country. In the emerging market country, the expansionary monetary policy is likely to cause expected inflation to rise dramatically and the domestic currency to depreciate sharply. As we have seen above, the depreciation of the domestic currency leads to a deterioration in firms' and banks' balance sheets because much of their debt is denominated in foreign currency, thus raising the burden of indebtedness and lowering banks' and firms' net worth. In addition, the upward jump in expected inflation is likely to cause

\footnotetext{
${ }^{11}$ For example, see Hausman and Gavin (1995).

12 See Mishkin (1996).
} 
interest rates to rise, causing interest payments to soar and the cash flow of households and firms to decline. Again, the result is a deterioration in households' and firm's balance sheets, and potentially greater loan losses to banks.

In the wake of a financial crisis, the net result of expansionary monetary policy given the institutional structure of financial markets in emerging market countries is that it hurts the balance sheets of households, firms and banks. Thus, in emerging market countries, expansionary monetary policy is not a viable policy to promote recovery from a financial crisis.

For similar reasons, lender of last resort actions by the central bank may not be as successful as in an industrialized country. Given the past record on inflation in an emerging market country, central bank lending to the financial system in the wake of a financial crisis which expands domestic credit might arouse fears of inflation spiraling out of control. We have already seen that if inflation expectations rise, leading to higher interest rates and exchange rate depreciation, cash flow and balance sheets will deteriorate making recovery from the financial crisis less likely. The lender of last resort role of a central bank must therefore be used far more cautiously in an emerging market country.

\section{Conclusion}

There are many lessons to be drawn from the Tequila Crisis, but there is a general theme in my remarks here. In designing appropriate policies for emerging market countries, it is essential that we take account of differences in the institutional structure of financial systems in these countries from those in industrialized countries.

\section{Acknowledgements}

I thank Dorothy Sobol and Charlie Calomiris for their helpful comments. Any views expressed in this paper are those of the author only and not those of Columbia University or the National Bureau of Economic Research, the Federal Reserve Bank of New York or the Federal Reserve System.

\section{References}

Bernanke, B.S., 1983. Non-monetary effects of the financial crisis in the propagation of the Great Depression. American Economic Review 73, 257-276.

Calomiris, C.W., 1999. Building an incentive-compatible safety net: Special problems for developing countries. Journal of Banking and Finance 23 (10), this issue. 
Calomiris, C.W., Gorton, G., 1991. The origins of banking panics: Models, facts and bank regulation. In: Hubbard, R.G. (Ed.), Financial Markets and Financial Crises, University of Chicago Press, Chicago, 109-173.

Diamond, D., 1984. Financial intermediation and delegated monitoring. Review of Economic Studies 51, 393-414.

Edwards, F., Mishkin, F.S., 1995. The decline of traditional banking: Implications for financial stability and regulatory policy. Federal Reserve Bank of New York Economic Policy Review 1 (3), 27-45.

Garber, P.M., Lall, S., 1996. The role and operation of derivative markets in foreign exchange crises. Brown University, Department of Economics, Providence, RI.

Hausman, R., Gavin, M., 1995. The roots of banking crises: The macroeconomic context. Mimeo., Inter-American Development Bank, Washington, DC, October.

Kaminsky, G.L., Reinhart, C.M., 1996. The twin crises: The causes of banking and balance of payments problems. Mimeo., Board of Governors of the Federal Reserve System, Washington, DC, February.

Mishkin, F.S., 1991. Asymmetric information and financial crises: A historical perspective. In: Hubbard, R.G. (Ed.), Financial Markets and Financial Crises, University of Chicago Press, Chicago, 69-108.

Mishkin, F.S., 1992. An evaluation of the treasury plan for banking reform. Journal of Economic Perspectives 6 (1), 133-153.

Mishkin, F.S., 1994. Preventing financial crises: An international perspective. Manchester School $62,1-40$.

Mishkin, F.S., 1996. Understanding Financial Crises: A Developing Country Perspective. Annual World Bank Conference on Development Economics. World Bank, Washington, DC, pp. 2962.

Mishkin, F.S., 1997. Evaluating FDICIA. In: Kaufman, G., (Ed.), Research in Financial Services: Private and Public Policy, vol. 9. FDICIA: Bank Reform Five Years Later and Five Years Ahead. JAI Press, Greenwich, CT, pp. 17-33.

Mishkin, F.S., 1998. Exchange-rate pegging for emerging market countries. International Finance, forthcoming.

Rojas-Suarez, L., Weisbrod, S.R., 1994. Financial market fragilities in latin america: from banking crisis resolution to current policy challenges. Working paper 94/117, IMF, Washington, DC, October.

Obstfeld, M., Rogoff, K., 1995. The mirage of fixed exchange rates. Journal of Economic Perspectives 9 (4), 73-96.

Stiglitz, J.E., Weiss, A., 1983. Incentive effects of terminations: Applications to credit and labor markets. American Economic Review 73, 912-927.

Stockman, A.C., 1999. Choosing an exchange-rate system. Journal of Banking and Finance 23 (10), this volume. 